\author{
Bakal Vitalii, \\ Candidate of Juridical Sciences, State \\ Research Institute MIA Ukraine, \\ Kyiv, Ukraine
}

ORCID ID 0000-0003-0019-7053

\title{
ADMINISTRATIVE AND LEGAL ASPECTS OF THE RESOURCE SUPPORT OF THE NATIONAL POLICE OF UKRAINE
}

The article investigates administrative and legal aspects of resource provision of the National Police of Ukraine. Based on the analysis of legal acts regulating the sphere of resource provision of the Ministry of Internal Affairs and the National Police of Ukraine, the content of the concept of "administrative-legal regulation of resource provision of police officers" is determined. A separate category - military supply - was studied as part of the material and technical support. The concepts of "resources", "financial resources", "material and technical resources" are studied. It was determined that the financial provision of the police is an activity that is carried out within the framework of the financial system of the state in all its manifestations and is a form of participation in the distribution of funds by obtaining financial resources for the timely and sufficient provision of mobile readiness of the police to carry out tasks to protect public order, the protection of constitutional rights and freedoms of citizens of Ukraine, as provided for in Article 2 of the Law of Ukraine "On the National Police".

It is stated that the totality of administrative-legal norms in the sphere of resource provision of the National Police of Ukraine, in its content, explains the essence and procedure of administrative and legal regulation in the sphere of resource provision of police officers by the relevant authorized subjects of management. Although the existing legal and regulatory instruments in the area of resources for the National Police are not perfect, they create an active system of administrative measures aimed at providing the National Police with financial, material and technical resources, as well as with the resources for military supplies necessary for the performance of the tasks 
assigned to the National Police of Ukraine in ensuring public safety and order; protection of human rights and freedoms, as well as the interests of society and the state; combating crime; providing, within the limits determined by law, assistance services to persons who need such assistance for personal, economic, social or emergency reasons.

Keywords: resource support, National Police of Ukraine, logistics, financial support, administrative and legal characteristics.

\section{REFERENCES}

1. Pro rezutaty audytu efektyvnosti vykorystannia biudzhetnykh koshtiv, vydilenykh na zabezpechennia diialnosti pidrozdiliv, ustanov ta zakladiv Natsionalnyi politsii Ukrainy. "On the results of the audit of the effectiveness of the use of budget funds allocated to support the activities of units, institutions and institutions of the National Police of Ukraine": the decision of the Accounting Chamber of April 11, 2018 No. 10-2. URL: R_RP_10-2_2018.pdf. (date of application: 10.09.2019) [in Ukrainian].

2. Pro Natsionalnu politsiiu Ukrainy. "On the National Police of Ukraine: Law of Ukraine dated 02.07.2015 No. 580-VIII”. IVR of Ukraine, 2015. No. 40-41 P. 1970. Art. 379. [in Ukrainian].

3. Lypii Ye.A. (2011) Administratyvno-pravove rehuliuvannia okhorony ekolohichnykh prav hromadian: poniattia ta zmist. "Administrative and legal regulation of protection of environmental rights of citizens: concept and content". The forum is right. No. 3. P. 468-472. [in Ukrainian].

4. Velykyi entsyklopedychnyi yurydychnyi slovnyk. "Great Encyclopedic Legal Dictionary" / ed. Acad. NAS of Ukraine Shemshenko. 2nd ed., Revised and supplemented by K.: Yurydychna Dumka, 2012. 1020 p. [in Ukrainian].

5. Bakal V.P. (2015) Administratyvno-pravovi zasady rechovoho zabezpechennia pratsivnykiv orhaniv vnutrishnikh sprav Ukrainy. "Administrative and legal bases of material support of employees of law-enforcement bodies of Ukraine": diss. Ph. D. in Law. 196 p. [in Ukrainian].

6. Slovnyk ukrainskoi movy: akademichnyi tlumachniy slovnyk (1970 - 1980): v 11 t. "Dictionary of the Ukrainian Language: Academic Interpretative Dictionary 
(1970 - 1980)": in 11 volumes URL: http: // sum.in.ua. (date of application: 09.10.2019) [in Ukrainian].

7. Velykyi tlumachnyi slovnyk suchasnoi ukrainskoi movy / [uklad. i holov. red. V.T. Busel]. "The Great Interpretive Dictionary of Modern Ukrainian" / [summary. and heads. ed. V.T. Stork]. K.; Irpin: VTF "Perun", 2003. 1440 p. [in Ukrainian].

8. Aleksandrova Z.Ye. (19896) Slovar sinonimov russkogo yazyka: okolo 9000 sinonimicheskikh ryadov. "Dictionary of Synonyms of the Russian Language: About 9000 Synonymic Series" / Ed. L.A. Czech. ed. 5th, stereotype. M.: Rus. language. 600 p. [in Russian].

9. Teslenko V.M. (1992) Pravovoye regulirovaniye materialno-tekhnicheskogo i voyennogo snabzheniya v sisteme MVD Rossiyskoy Federatsii. "Legal regulation of material and technical and military supplies in the system of the Ministry of Internal Affairs of the Russian Federation": author. diss. Ph. D. in Law. K. [in Russian].

10. Bandurka O.M. (2004) Teoriia i praktyka upravlinnia orhanamy vnutrishnikh sprav Ukrainy. "Theory and Practice of Managing Internal Affairs Bodies of Ukraine": Monograph. Kh. [in Ukrainian].

11. Ilnytskyi M.S. (2009) Orhanizatsiia finansovoho ta materialno-tekhnichnoho zabezpechennia orhaniv vnutrishnikh sprav Ukrainy. "Organization of financial and logistical support of law-enforcement bodies of Ukraine". Forum by right. No. 1. P. 222-230 URL: http://www.nbuv.gov.ua/ejournals/FP/2009-1/09imcvcu.pdf] (date of application: 09.10.2019) [in Ukrainian]. 